\title{
The GAMDAM glacier inventory: a quality-controlled inventory of Asian glaciers
}

\author{
T. Nuimura ${ }^{1, \mathrm{a},{ }^{*}}$, A. Sakai ${ }^{1,{ }^{*}}$, K. Taniguchi ${ }^{1, \mathrm{~b}}$, H. Nagai ${ }^{1, \mathrm{c}}$, D. Lamsal $^{1}$, S. Tsutaki ${ }^{1, \mathrm{~d}, \mathrm{e}}$, A. Kozawa ${ }^{1}$, Y. Hoshina ${ }^{1}$, \\ S. Takenaka ${ }^{1}$, S. Omiya ${ }^{1, \mathrm{f}}$, K. Tsunematsu ${ }^{1, \mathrm{~g}}$, P. Tshering ${ }^{1, \mathrm{~h}}$, and K. Fujita ${ }^{1}$ \\ ${ }^{1}$ Graduate School of Environmental Studies, Nagoya University, Nagoya, Japan \\ ${ }^{a}$ now at: Chiba Institute of Science, Choshi, Japan \\ b now at: Fukushima Prefecture, Fukushima, Japan \\ c now at: Japan Aerospace Exploration Agency, Tsukuba, Japan

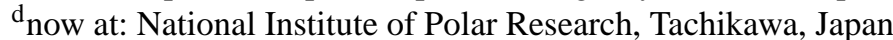 \\ enow at: Institute of Low Temperature Science, Hokkaido University, Sapporo, Japan \\ ${ }^{f}$ now at: Civil Engineering Research Institute for Cold Region, Sapporo, Japan

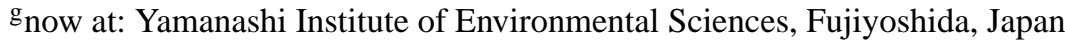 \\ ${ }^{h}$ now at: Department of Geology and Mines, Thimphu, Bhutan \\ *These authors contributed equally to the manuscript.
}

Correspondence to: T. Nuimura (tnuimura@cis.ac.jp) and A. Sakai (shakai@nagoya-u.jp)

Received: 29 April 2014 - Published in The Cryosphere Discuss.: 3 June 2014

Revised: 9 April 2015 - Accepted: 9 April 2015 - Published: 6 May 2015

\begin{abstract}
We present a new glacier inventory for highmountain Asia named "Glacier Area Mapping for Discharge from the Asian Mountains" (GAMDAM). Glacier outlines were delineated manually using 356 Landsat ETM+ scenes in 226 path-row sets from the period 1999-2003, in conjunction with a digital elevation model (DEM) and highresolution Google Earth ${ }^{\mathrm{TM}}$ imagery. Geolocations are largely consistent between the Landsat imagery and DEM due to systematic radiometric and geometric corrections made by the United States Geological Survey. We performed repeated delineation tests and peer review of glacier outlines in order to maintain the consistency and quality of the inventory. Our GAMDAM glacier inventory (GGI) includes 87084 glaciers covering a total area of $91263 \pm 13689 \mathrm{~km}^{2}$ throughout high-mountain Asia. In the Hindu Kush-Himalaya range, the total glacier area in our inventory is $93 \%$ that of the ICIMOD (International Centre for Integrated Mountain Development) inventory. Discrepancies between the two regional data sets are due mainly to the effects of glacier shading. In contrast, our inventory represents significantly less surface area $(-24 \%)$ than the recent global Randolph Glacier Inventory, version 4.0 (RGI), which includes $119863 \pm 9201 \mathrm{~km}^{2}$ for the entirety of high Asian mountains. Likely causes of this
\end{abstract}

disparity include headwall definition, effects of exclusion of shaded glacier areas, glacier recession since the 1970s, and inclusion of seasonal snow cover in the source data of the RGI, although it is difficult to evaluate such effects quantitatively. Further rigorous peer review of GGI will both improve the quality of glacier inventory in high-mountain Asia and provide new opportunities to study Asian glaciers.

\section{Introduction}

The state and fate of Asian glaciers (Bolch et al., 2012) have important implications for both regional water resources (e.g. Immerzeel et al., 2010; Kaser et al., 2010) and future sea level rise (e.g. Radić and Hock, 2011; Gardner et al., 2013). Changes in glacier mass have been documented and/or estimated using a variety of approaches, such as in situ measurements (Fujita and Nuimura, 2011; Yao et al., 2012), numerical modelling (Immerzeel et al., 2010; Radić and Hock, 2011), and remote sensing (Matsuo and Heki, 2010; Jacob et al., 2012; Kääb et al., 2012; Gardelle et al., 2013; Gardner et al., 2013), in order to understand modern spatial variability in high-mountain Asia. However, discrepancies exist among es- 
timates based on these different methods (e.g. Cogley, 2012; Gardner et al., 2013).

A glacier inventory is a fundamental component of regional projections of mass balance and glacier discharge. For example, glacier hypsometry (area-elevation distribution) directly affects estimates of mass balance, discharge, and modelled contribution to sea level rise (Raper and Braithwaite, 2005), while uncertainty in glacier outline influences estimates of mass changes using laser altimetry (Kääb et al., 2012; Gardner et al., 2013). To support the Fifth Assessment of the Intergovernmental Panel on Climate Change (IPCC), the global Randolph Glacier Inventory (RGI) was published (Pfeffer et al., 2014). However, while the majority of glacieroutline data used in that study were derived from recent satellite imagery, glacier extents in China were incorporated from an inventory dating from 1956 to 1983 . For brevity, we refer to this Chinese inventory as being from the 1970s (Shi, 2008). In December 2014, the second Chinese glacier inventory was released. However, this new data set has not been incorporated into the RGI ver. 4.0 (Arendt et al., 2014) employed in this study. Furthermore, a small number of the glaciers used in the RGI are undated (Pfeffer et al., 2014).

In 2011, we launched a project, entitled Glacier Area Mapping for Discharge in Asian Mountains (GAMDAM), with the goal of investigating the contribution of glacier meltwater to Asian river systems. Our initial and main purpose for creating the glacier inventory is to estimate the elevation change of glaciers in Asian mountain areas, which is equivalent to evaluating the effect of glacier volume change on river run-off (Kääb et al., 2012). Here, we describe the materials and procedures used to delineate glacier outlines over high-mountain Asia and show preliminary comparisons of our GAMDAM glacier inventory (GGI) to the RGI and a glacier inventory produced by Bajracharya and Shrestha (2011) (ICIMOD inventory; ICIMOD: the International Centre for Integrated Mountain Development, Kathmandu, Nepal) for the Hindu Kush-Himalayan (HKH) region.

Our target region covers high-mountain Asia between 67.4 and $103.9^{\circ} \mathrm{E}$ longitude and 27.0 and $54.9^{\circ} \mathrm{N}$ latitude, which corresponds to the regions of central Asia, southwestern Asia, southeastern Asia, and Altay and Sayan of northern Asia in the RGI (Arendt et al., 2014; Pfeffer et al., 2014). Pfeffer et al. (2014) have provided $62606 \mathrm{~km}^{2}$ with $8.4 \%$ error, $33859 \mathrm{~km}^{2}$ with $7.7 \%$ error, $21799 \mathrm{~km}^{2}$ with $8.3 \%$ error, and $1803 \mathrm{~km}^{2}$ with $10.3 \%\left(<54.9^{\circ} \mathrm{N}\right)$ error in these regions, respectively.

\section{Data sets}

We analysed 356 Landsat level 1 terrain-corrected (L1T) scenes in 226 path-row sets available from USGS EarthExplorer (http://earthexplorer.usgs.gov/), for the period 19992003 (Table S1 in the Supplement), prior to the 2003 fail-

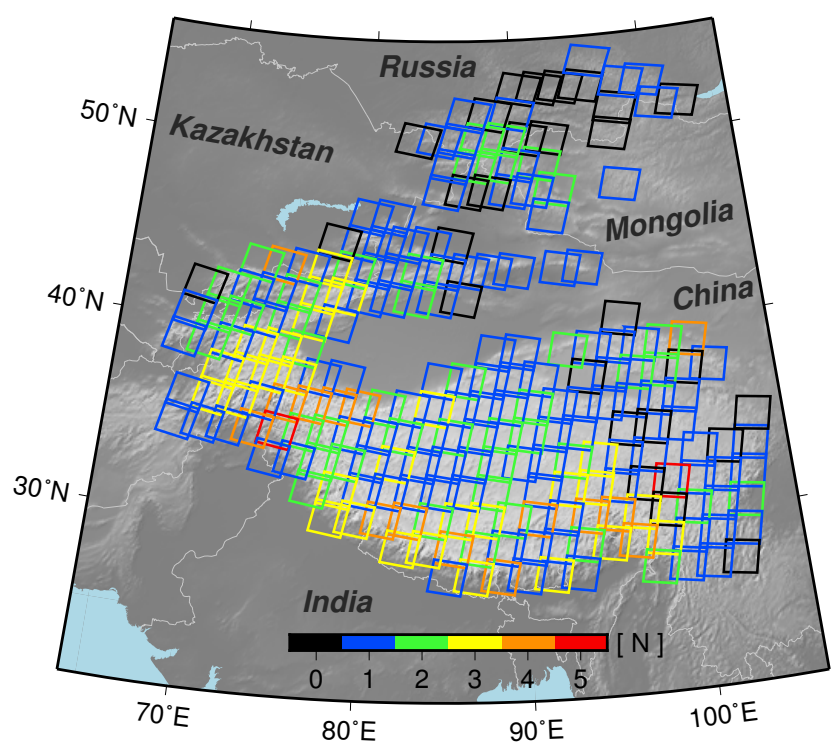

Figure 1. Footprints of Landsat scenes used in this study to delineate glaciers over high-mountain Asia. Colours refer to the number $[\mathrm{N}]$ of scenes used, while zero values (black squares) indicate that no glaciers exist in that scene.

ure of the scan line corrector (SLC). Systematic radiometric and geometric corrections were performed for the L1T imagery using the Global Land Survey digital elevation model (DEM) 2000, which is a merged product comprising the Shuttle Radar Topography Mission (SRTM) DEM (http://landsat.usgs.gov/LandsatProcessing_Details.php) and other DEMs. We selected Landsat scenes with minimal cloud and snow cover from paths $130-154$ and rows $22-41$ in the Worldwide Reference System 2. In regions where seasonal snow and cloud cover frequently hamper the identification of glacier limits (e.g. Karakoram, Himalayas, and Hengduan Shan), we used multiple scenes to increase accuracy (Fig. 1). If we were unable to obtain perfect (i.e. free of both seasonal snow and cloud cover) imagery for a certain pathrow scene, we searched other partially clear images to obtain clear glacier outlines for whole glaciers. In addition, we utilised both wintertime and summertime imagery, since the former are unaffected by monsoon cloud or seasonal snow in the monsoon-affected area and therefore can be used for the delineation of glaciers on south-facing slopes. Details of this methodology are given in Sect. 3.3. Images lacking glaciers are shown in Fig. 1 as "zero scene". Where appropriate Landsat ETM+ scenes were unavailable, we utilised Landsat TM scenes collected prior to 1999 (two scenes, Table S1).

To delineate glacier outlines topographically, we used contours (20 $\mathrm{m}$ intervals) and slope distribution overlain on the satellite scenes. These topographic data were generated using a gap-filled DEM from the SRTM (Jarvis et al., 2014) and are compatible with the L1T imagery because the latter is corrected using the SRTM. Although a recent report as- 
serts the ASTER GDEM has superior accuracy to the SRTM (Hayakawa et al., 2008), that evaluation was made over a non-glaciated region. Therefore, in our analysis of median glacier elevation, we compared the SRTM and the most recent version of the ASTER GDEM version 2 (GDEM2, released in 2011) using the laser-altimetry product ICESat GLA14 (Kääb, 2008), as described in Sect. 3.2.

We compared the GGI to both the RGI (Pfeffer et al., 2014) and the ICIMOD glacier inventory (Bajracharya and Shrestha, 2011). The RGI is a collection of digital outlines of the world's glaciers. Although the inventory includes some misinterpreted polygons and limited attribute data, the RGI remains the only glacier inventory with global coverage (excluding the ice sheets in Greenland and in Antarctica). Furthermore, it is the only data set comparable to our glacier inventory. For our comparison here, we used version 4.0 of the RGI (released 1 December 2014) (Arendt et al., 2014).

We also compared the GGI with the ICIMOD inventory (Bajracharya and Shrestha, 2011), which covers the HKH region (the Amudarya, Indus, Ganga, Brahmaputra and Irrawaddy basins) and Chinese region (the Salween, Mekong, Yangtze, Yellow, and Tarim Interior basins, and QinghaiTibetan Plateau). The ICIMOD inventory was generated semi-automatically using more than 200 Landsat 7 ETM+ images taken between 2002 and 2008. Polygon data for the HKH Region are available at http://apps.geoportal.icimod. org/HKHGlacier/\#. We employed these data to make detailed inter-inventory comparisons of total glacier area for the $\mathrm{HKH}$ region (Table 2).

\section{Methods}

\subsection{Pre-processing}

We used the Landsat scenes to generate both true-colour (bands 3, 2, and 1 as RGB) and false-colour (bands 7, 4, and 2 as RGB) composite images at $30 \mathrm{~m}$ resolution. Composite colour-band weight was adjusted automatically using image contrast and GIS software. True-colour composite images were used primarily for glacier delineation. False-colour images enabled us to differentiate ice from cloud owing to the strong absorption of ice/snow in the SWIR compared with clouds. Additionally, we employed thermal infrared (band 6) at $60 \mathrm{~m}$ resolution to identify ice with a thin debris cover. Due to the time-intensive nature of manually delineating glaciers in high-resolution imagery (Bhambri et al., 2011), we did not adopt a pan-sharpening method using $15 \mathrm{~m}$ resolution images (band 8).

For debris-free glaciers, automated delineation using the spectral ratio is more consistent and reproducible than manual delineation (Paul et al., 2013). For example, Fig. 2 compares manual and automated delineations of debris-free glacier area using Landsat imagery that is free of cloud and seasonal snow cover. It shows that glacier outlines gener-

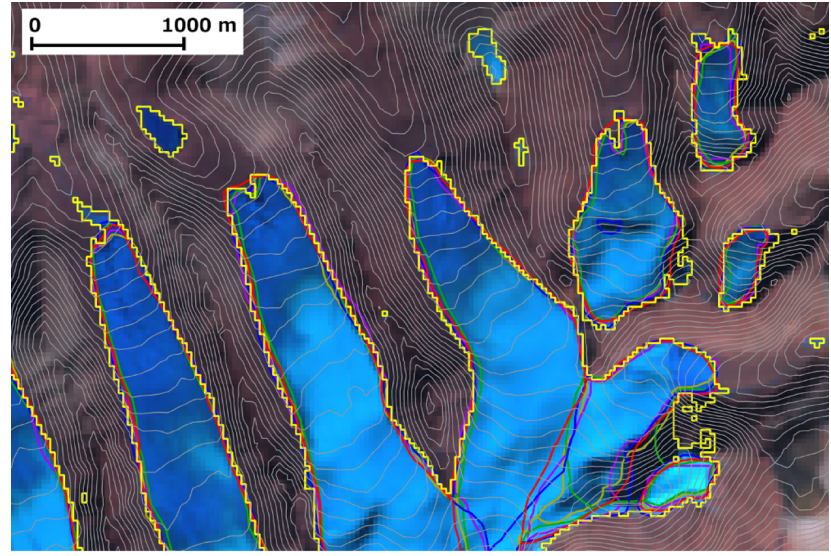

Glacier outlines generated by automated mapping

Glacier outlines manually delineated by operators

Figure 2. Comparison of debris-free glacier delineation at $28.380^{\circ} \mathrm{N}, 86.472^{\circ} \mathrm{E}$, using automated mapping derived from the band ratio method (grid cells with band3/band5 $>1.8$ are glacier ice; Paul et al., 2013) and manual delineation. Background imagery is Landsat false-colour (bands 7, 4, and 2 as RGB) composite imagery, taken on 5 January 2002, at path 145 row 039.

ated manually exhibit a difference of approximately $\pm 1-$ 2 grid cells from those generated through automated mapping (Fig. 2). Furthermore, manual delineation often failed to identify small glaciers. However, we did not employ automated mapping for the GGI for the following reason: in high-mountain Asia there is an abundance of debris-covered glaciers, particularly in the Himalaya and the Karakoram ranges.

We generated contour lines, basin polygons, and slope distribution from SRTM data. Contour lines were then used to delineate the termini of debris-covered glaciers and outlines of shaded glacier sections (see Sect. 3.2), and to divide glacier polygons. To avoid misinterpretation of ice divides due to potentially erroneous interpolation of the gap-filled SRTM (Frey et al., 2012), we chose not to use basin polygons to separate ice divides automatically. Instead, we referred to contour lines in order to identify glacier divides.

\subsection{Digital elevation models}

We tested the SRTM output to that of the GDEM2, focusing on glacier polygons exhibiting inter-model elevation differences of $>100 \mathrm{~m}$. Upon comparing the two DEMs to the ICESat GLA 14 (Fig. 3a), we found that elevations in the GDEM2 are consistent with those of ICESat, with a slight bias of $+40 \mathrm{~m}$ relative to ICESat. In contrast, elevations derived from the SRTM show a significantly negative bias of $-99 \mathrm{~m}$ relative to ICESat, as well as a larger analytical uncertainty (Fig. 3b). 


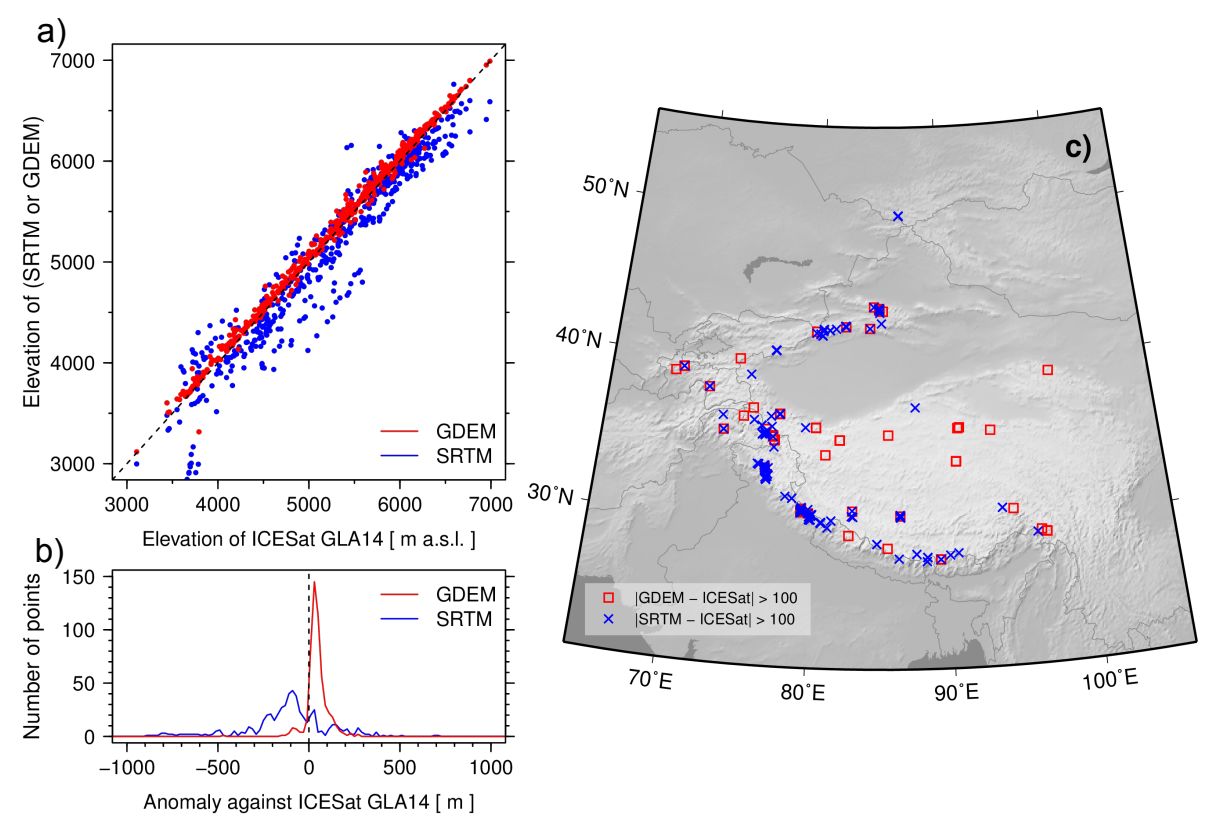

Figure 3. Evaluation of DEMs based on ICESat GLA14. Where large ( $>100 \mathrm{~m})$ differences exist between SRTM and ASTER GDEM (version 2) data sets, we compared modelled elevations to those of ICESat GLA14: (a) scattergram, (b) histogram, and (c) spatial distribution.

The distribution of elevation differences indicates that significant error in the SRTM occurs along the Karakoram and Himalaya ranges and in the central Tien Shan, while significant error in the GDEM2 occurs locally throughout the central Tibetan Plateau (Fig. 3c). In the Karakoram and Himalayas, high-relief topography resulted in numerous voids in the original SRTM-3 product (Frey et al., 2012), thereby resulting in the considerable errors observed there. Meanwhile, the low relief and decreased colour contrast of snowfields on the Tibetan Plateau may be responsible for the large uncertainty in the GDEM2, which was created by optical stereo photogrammetry. Therefore, considering the relatively small uncertainty in the GDEM2 for the entire highmountain Asia region (Fig. 3a and b), we conclude that the GDEM2 is more appropriate for glacier-altitude analysis in high-mountain Asia.

\subsection{Criteria for manual delineation}

According to the Global Land Ice Measurements from Space (GLIMS) protocol (Raup and Khalsa, 2007; Racoviteanu et al., 2009), all perennial snow masses must be included as glaciers, and only exposed ground can be excluded. Above the bergschrund, ice bodies that are connected to the glacier below shall also be considered part of the glacier. In our study, however, we excluded steep headwalls even where snow covered, since avalanching precludes development of a permanent ice cover there. Although this avalanching is an important source of glacier nourishment, steep headwalls generally do not experience changes in surface elevation related to glacier mass fluctuations.
As satellite imagery documents only a single point in time, distinguishing between glacier ice and snow-covered rock headwalls and valley sides can be difficult. Consequently, previous studies have delineated glacier outlines differently at upper headwalls depending on the image source utilised. On the Khumbu Glacier in Nepal, for example, variable glacier-outline delineations along steep headwalls are the result of varying surface snow/ice conditions among the images used (e.g. Salerno et al., 2008; Bolch et al., 2011; Thakuri et al., 2014). In addition, dry slab avalanches are common on headwalls steeper than $40^{\circ}$ (McClung and Schaerer, 2006). Therefore, where a headwall gradient exceeds $40^{\circ}$ (coloured in yellow to brown in Fig. 4b), we checked the surface condition of the wall in Google Earth ${ }^{\mathrm{TM}}$ and excluded those slopes with a longitudinal plicate surface (Fig. 4c, purple) or thinly snow-covered rock walls (Fig. 4c, orange). Figure 4 shows an example of the steep headwalls excluded from our inventory.

Where glacier surfaces are largely free of debris, delineation of the ice surface was possible using false-colour composite imagery, which can distinguish glacier surfaces from cloud cover (Fig. 5c and d). Similarly, we employed falsecolour imagery to identify boundaries of thinly dust-covered glaciers (Fig. 6). By contrast, we used contour lines to delineate indistinct boundaries of debris-covered ablation zones (Fig. 7a), since contour lines tend to exhibit clear inflections at their intersection with glacier outlines. On debrismantled glacier surfaces, areas of relatively thin debris cover, which have relatively low surface temperature, were delineated using thermal infrared band (Fig. 7b). Identification of thermokarst features, such as rugged surface topography, was verified with high-resolution Google Earth ${ }^{\mathrm{TM}}$ images, which 


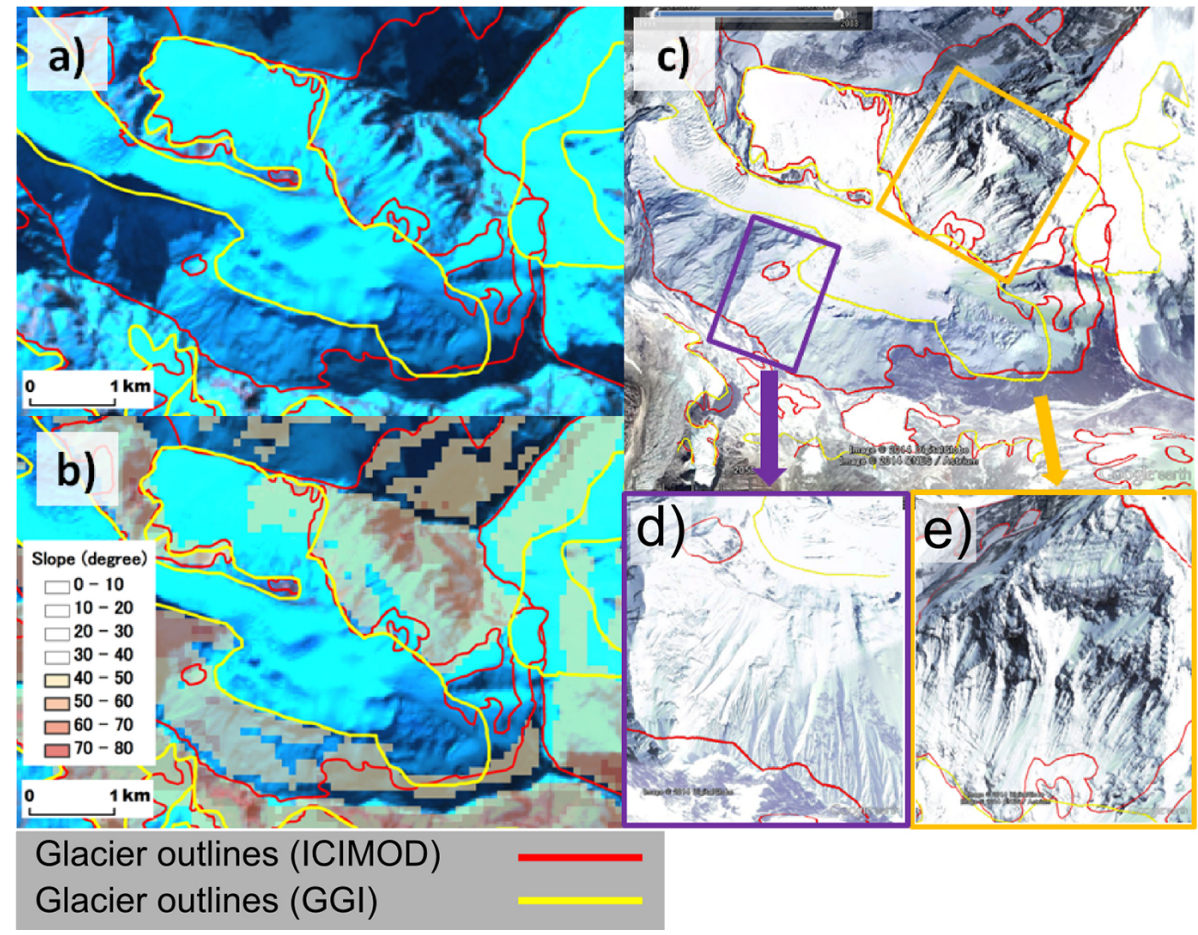

Figure 4. Example of an excluded steep headwall of the Khumbu Glacier. The background is false colour (bands 7, 4, and 2 as RGB) composite Landsat imagery, taken on 30 October 2000 , at path 140 row $41\left(99.38^{\circ}\right.$ E, $\left.35.70^{\circ} \mathrm{N}\right)(\mathbf{a}, \mathbf{b})$. Steep $\left(>40^{\circ}\right)$ headwalls $(\mathbf{c}, \mathbf{d}$, e) were not included as glacier area, since accumulation cannot occur on longitudinally plicate surfaces (d) or where rock surfaces are only thinly snow-covered (e). Not all slopes with $>40^{\circ}$ inclination were excluded from the GGI: gradient was used as a guide only. Glacier outlines of RGI ver. 4.0 at the Khumbu Glacier equate to those of the ICIMOD glacier inventory.

can identify exposed ice cliffs on the debris-covered glacier (Fig. 7c). Non-glacial lakes surrounded by smooth terrain can also be identified in Google Earth ${ }^{\mathrm{TM}}$ imagery (Fig. 7d). This method is effective for the delineation of terminus outlines on debris-covered glaciers.

We used both winter and summer Landsat images for one path-row scene to avoid shade, cloud, and seasonal snow cover. Examples of glacier-outline delineations made using these two types of imagery are shown in Fig. 5. The Landsat imagery exhibits greater seasonal snow cover on southfacing slopes (Fig. 5a), whereas imagery collected on $2 \mathrm{Au}-$ gust 2002 shows shading on north-facing slopes (Fig. 5b). Therefore, glacier outlines in shaded areas are delineated based on the image of Fig. 5a, while glaciers on south-facing slopes are delineated using the image of Fig. 5b. Landsat imagery taken on 20 October 2001 contains partial cloud cover but less shading (Fig. 5c), whereas imagery taken on 1 August 2001 contains no cloud cover but greater shading (Fig. 5d). In this case, the cloud-obscured glacier area shown in Fig. $5 \mathrm{c}$ was delineated using the image shown in Fig. $5 \mathrm{~d}$ (pink line), while shaded areas in Fig. 5d were delineated using the image shown in Fig. 5c (yellow line). In this delineation phase, we made different polygon files for each image source (i.e. one path-row scene comprises multiple polygon file sets). We then added the Landsat image ID as attribute data for each glacier when merging these polygon data.

Furthermore, where we could obtain clear (i.e. free of seasonal snow and cloud) wintertime but not summertime imagery, slope transition zones (indicated by a change in the spacing of contour lines) are used to indicate the glacier outline (Paul et al., 2004) in areas of shade, as shown in Fig. 8. Additionally, SLC-off scenes (Landsat ETM+ post-dating May 2003) were used to identify ambiguous glacier boundaries when clear Landsat L1T imagery or Google Earth ${ }^{\mathrm{TM}}$ imagery was unavailable, though we note their acquisition dates are different from those of L1T scenes. Some glacierlike areas visible on Landsat scenes (Fig. 9a) were identified later as seasonal snow in Google Earth ${ }^{\mathrm{TM}}$ images (Fig. 9b).

In the final aggregation process, we excluded small glaciers $\left(<0.05 \mathrm{~km}^{2}\right)$, which is the same as the threshold employed by Rastner et al. (2012). The minimum area of $0.05 \mathrm{~km}^{2}$ corresponds to about 55 grids of Landsat images (band $1-5,7$ ) with $30 \mathrm{~m}$ resolution.

\subsection{Quality control}

Considerable variability among measurements of glacier area is possible owing to different interpretations of glacier boundaries (Paul et al., 2013), as well as personnel changes 

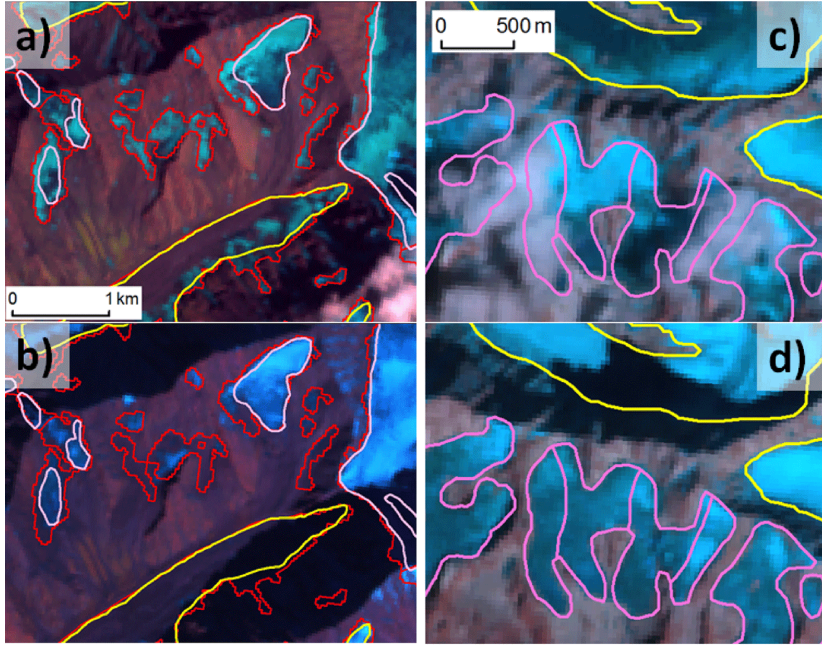

Glacier outlines with shadow area (GGI)

Glacier outlines on south-facing slopes (GGI)

Glacier outlines by automated mapping (RGI)

Figure 5. Two examples where multiple images were required to delineate glacier outline for a single path-row scene because of seasonal cover/partial cloud cover or shade: $(\mathbf{a}, \mathbf{b})$ at $76.856^{\circ} \mathrm{E}$, $32.512^{\circ} \mathrm{N}$ (path 147 row 38); (c, d) at $79.357^{\circ} \mathrm{E}, 30.824^{\circ} \mathrm{N}$ (path 145 row 039). All background imagery is false colour (bands 7, 4, and 2 as RGB). The Landsat imagery, taken on 15 October 2001 .

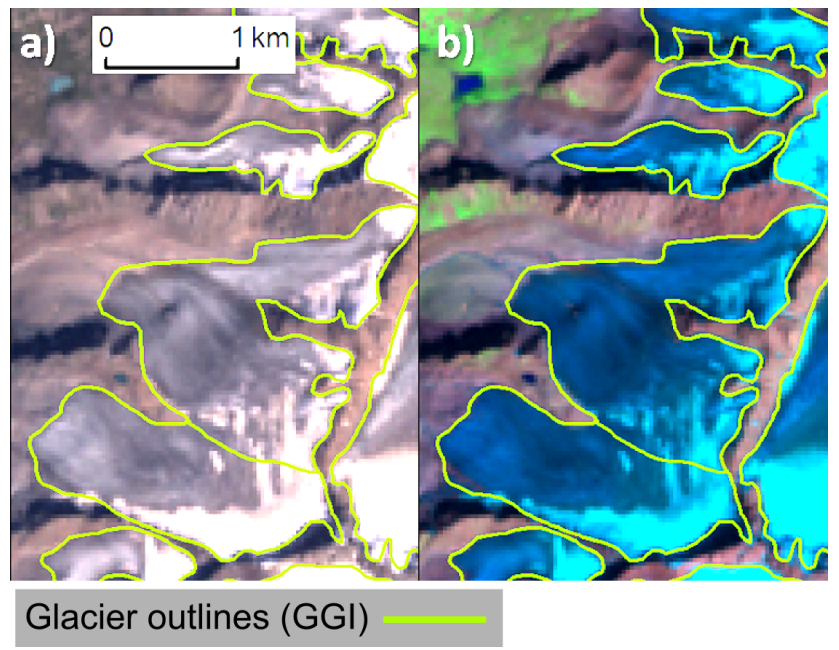

Figure 6. Thinly dust-covered glaciers located at $42.316^{\circ} \mathrm{N}$, $78.833^{\circ} \mathrm{E}$ (path 148 row 31). Identification of such glaciers is problematic (i.e. they show only black surfaces) using true-colour (bands 3, 2, and 1 as RGB) composite imagery (a) but relatively straightforward using false-colour (bands 7, 4, and 2 as RGB) composite imagery (b). Background imagery was acquired on $25 \mathrm{Au}-$ gust 2002.
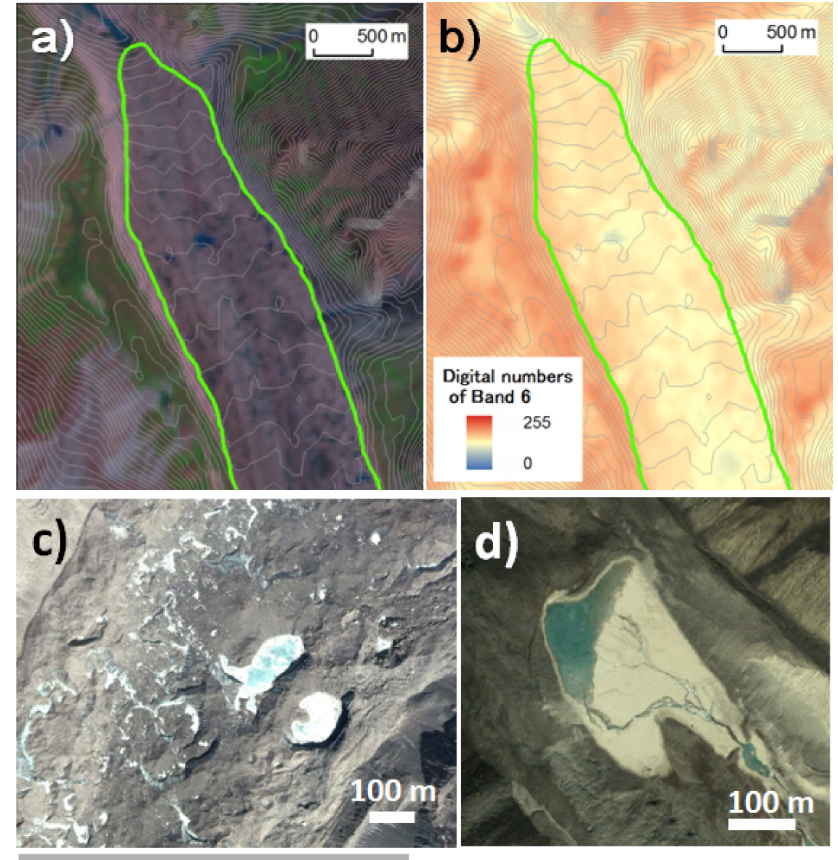

Glacier outlines

Figure 7. Example of glacier outlines generated for the GGI using contour lines at $20 \mathrm{~m}$ intervals. The full extent of debris-covered glacier surfaces can be identified using both the inflections of contour lines (a) and thermal band imagery (band 6) (b). Background imageries are false colour (bands 7, 4, and 2 as RGB) (a) and thermal band (band 6) (b) Landsat imagery $\left(30.911^{\circ} \mathrm{N}, 79.088^{\circ} \mathrm{E}\right)$ acquired on 1 August 2001, at path 145 row 39. Thermokarst features and supra-glacial lakes with ice cliffs $\left(27.911^{\circ} \mathrm{N}, 86.949^{\circ} \mathrm{E}\right)$ (c) and a non-glacial lake surrounded by smooth terrain $\left(28.083^{\circ} \mathrm{N}\right.$, $86.471^{\circ} \mathrm{E}$ ) (d) are used to differentiate between debris-covered glacier surfaces and ice-free areas. Both (c) and (d) are screenshots from Google Earth ${ }^{\mathrm{TM}}$, ${ }^{\circ} 2014$ DigitalGlobe.

over the course of the project. Figure 10 depicts several examples where glacier boundaries were delineated differently. For example, orange lines depict the erroneous inclusion of steep rock walls (indicated by yellow arrow) in an accumulation zone at $28.74^{\circ} \mathrm{N}, 84.39^{\circ} \mathrm{E}$. Google Earth ${ }^{\mathrm{TM}}$ imagery reveals partially exposed bedrock on steep headwalls, which were not included as glacier area according to our criteria (Fig. 10a). In a debris-covered ablation zone $\left(28.78^{\circ} \mathrm{N}\right.$, $84.32^{\circ} \mathrm{E}$ ), yellow dotted circles indicate areas misidentified as glacier ice. Red, blue, and light-green lines represent correctly delineated debris-covered glacier area (Fig. 10b). Therefore, we conducted a total of five delineation tests (Table S2) in order to ensure adherence to the delineation criteria and to homogenise the quality of our inventory. In these five tests, we evaluated delineations made by each operator and provided feedback in order to minimise differences among output and to improve delineation accuracy. Accordingly, the errors described above were corrected and the operators were advised of these problems. 
a)

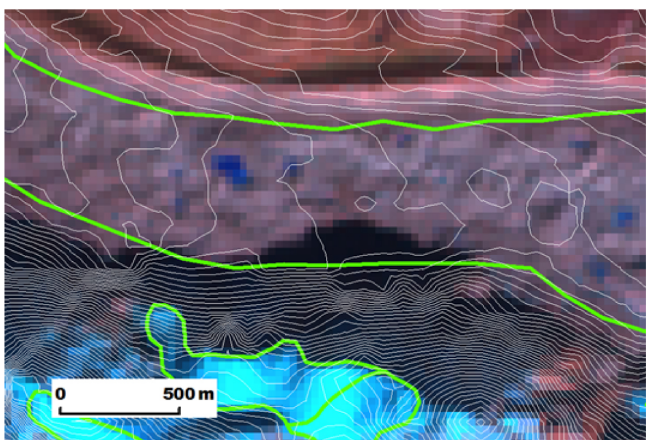

b)

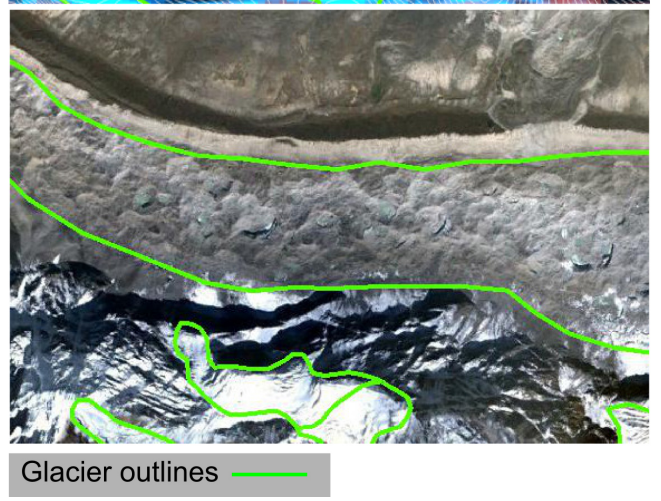

Figure 8. Example of glacier outlines generated with contour lines at path 140 row 41 of Landsat imagery $\left(27.991^{\circ} \mathrm{N}, 86.730^{\circ} \mathrm{E}\right)$, taken on 30 October 2000 (a), and Google Earth, ${ }^{{ }^{2}} 2015$ DigitalGlobe screenshots of the same location (b). When summertime (high solar angle) Landsat imagery lacking seasonal snow cover was unavailable, we employed wintertime (low solar angle) imagery. In that case, glacier outlines in shaded areas were delineated by reference to slope-change boundaries indicated by contour intervals.

Initial delineation of glacier outlines was carried out by 11 operators over a period of 20 months, during which time the quality of delineation might have varied significantly. Operators can be classified as those with field experience on glaciers (e.g. with glaciological knowledge and experience of remote sensing) and those without. Consequently, glacier polygons delineated by non-experienced operators were reviewed by field-experienced operators. Figure 11 shows an example where the second operator corrected the polygon delineated by the first, by using different source imagery. Whereas the first operator delineated glacier outlines using Landsat imagery with a low solar angle and seasonal snow cover (Fig. 11a), the second employed summertime imagery containing less seasonal snow cover (Fig. 11b), thereby enabling shaded glacier areas to be incorporated. Following this peer review of glacier outlines, topological properties were checked. For example, overlapping polygons may cause overestimation of glacier area (Fig. S1a in the Supplement), while irregular polygons (e.g. self-intersecting polygons; Fig. S1b) cannot represent the glacier area accurately. Such mis-delineations were detected automatically by GIS functions and then corrected.

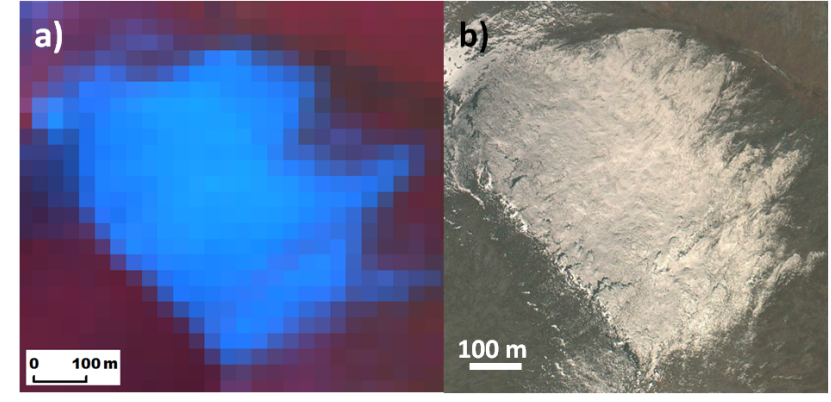

Figure 9. Glacier-like seasonal snow cover seen in false-colour (bands 7, 4, and 2 as RGB) composite imagery at path 140 row 41 $\left(27.984^{\circ} \mathrm{N}, 87.657^{\circ} \mathrm{E}\right)$, taken on 17 October 2001 (a), and Google Earth, ${ }^{\circ} 2014$ DigitalGlobe screenshots of the same location (b). We can distinguish between such snow cover and glacier ice using highresolution Google Earth ${ }^{\mathrm{TM}}$ imagery, which reveals that the surface is undulating and has the appearance of thin snow on a rock surface.

\subsection{Attribute data}

We attached 15 attributes to every glacier analysed. Each glacier is assigned a unique ID consisting of a sequential 6digit number, beginning with id $=000001$ in p130r037 and ending with id $=087084$ in p154r033. The highest ID corresponds to the total number of glaciers in the GGI. Path, row, granule ID, and acquisition date of the Landsat scene, as well as the name of the operator, are included to enable traceability and validation by others. In addition, basic geographic information - such as longitude, latitude, and area - is provided together with elevation data (mean, median, maximum, minimum, range, and mid-range elevation), which were derived from GDEM2 (Table S3). We also provided records of the peer review and revision of glacier outlines (reviewer name and date) that were performed on each scene (Table S4). These records will permit others to validate our inventory and analyse changes in glacier extent over time using another inventory.

\subsection{Evaluation of uncertainties}

We evaluated uncertainty in glacier delineation using the results of five separate delineation tests (Fig. 12). Here, uncertainty is defined as one normalised standard deviation, calculated as the standard deviation of the glacier area measured by different operators divided by the mean value of the glacier area measured by all operators. Figure 12 shows that the normalised standard deviation decreases with increasing glacier area. Specifically, large glaciers $\left(>2.5 \mathrm{~km}^{2}\right)$ exhibit lower normalised standard deviations $(<15 \%)$ than smaller glaciers $\left(<2.5 \mathrm{~km}^{2}\right.$ area; $>25 \%$ standard deviation). A debris-covered glacier gives a normalised standard deviation of approximately $10 \%$. In summary, the uncertainty of delineated glacier areas in the GGI is less than $25 \%$ for small glaciers and $\sim 15 \%$ for large glaciers. Therefore, we expect 
a)

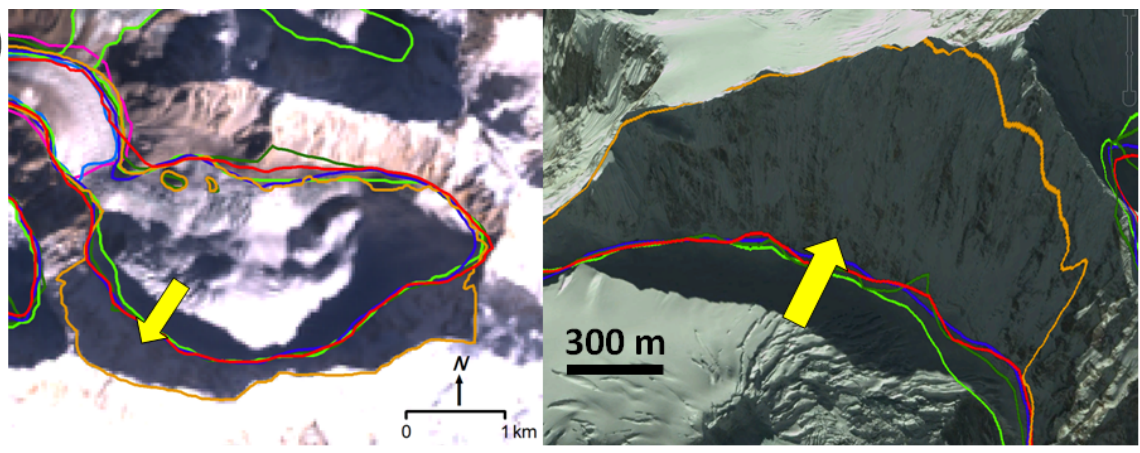

b)

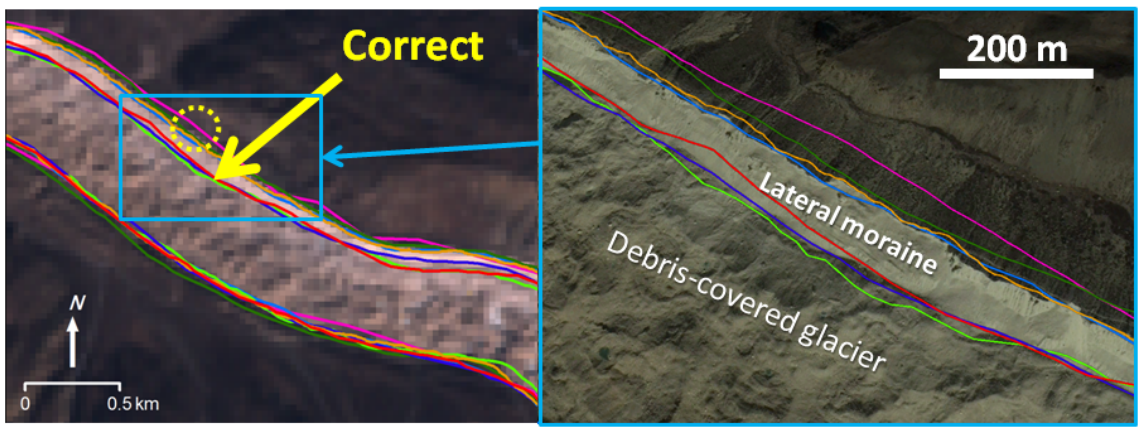

Figure 10. Examples of delineation tests, in which coloured lines represent glacier outlines delineated by different operators. Both background images (left panels) are true-colour composites of the Landsat ETM+ scenes. Right-hand panels in both (a) and (b) are Google Earth $^{\mathrm{TM}}$ screenshots, ${ }^{\circ} 2014$ DigitalGlobe.

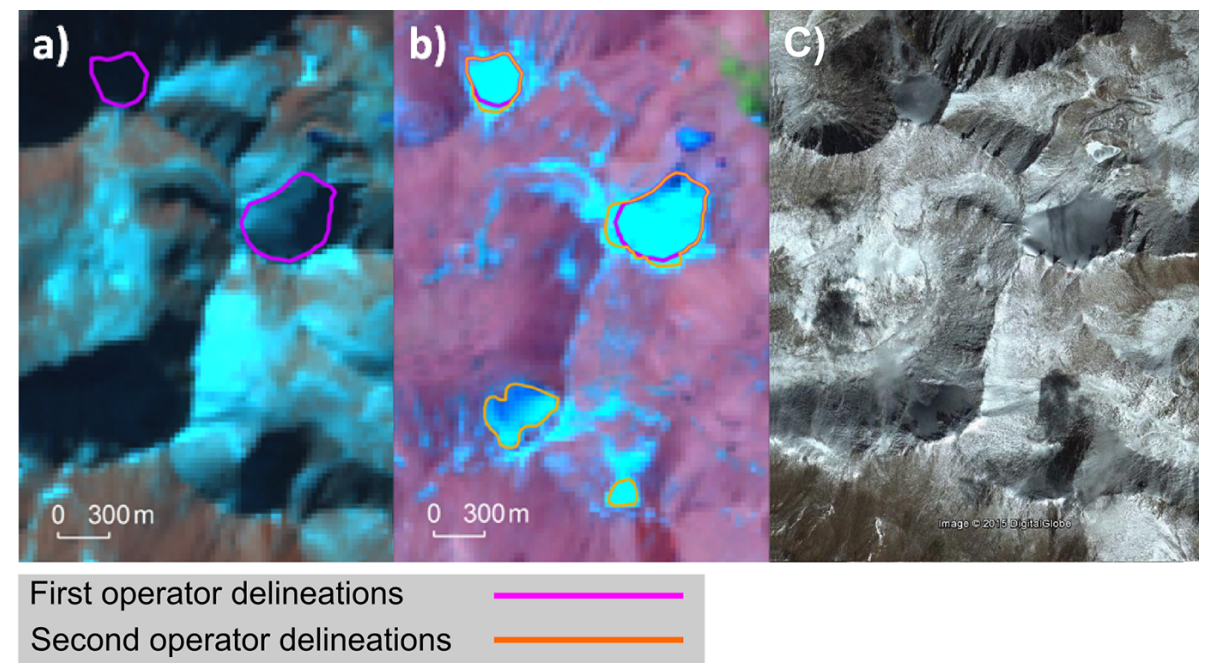

Figure 11. Example of glacier-outline retrieval by a second operator using Landsat imagery path 133 row $035\left(35.70^{\circ} \mathrm{N}, 99.38^{\circ} \mathrm{E}\right)$. Background images are false-colour (bands 7, 4, and 2 as RGB) composites taken on (a) 7 January 2003 and (b) 12 July 2001 , in addition to Google Earth ${ }^{\mathrm{TM}}$ imagery (c).

approximately $15 \%$ uncertainty in our glacial area computation. In its current form, the GGI has a relatively large uncertainty, which incorporates all differences in glacier outlines delineated by $5-8$ operators. We anticipate that rigorous peer review by field operators will reduce this uncertainty in the future.

\section{Results}

\subsection{Distribution of glaciers and their median elevations}

We delineated a total of 87084 glaciers with a total area of $91263 \pm 13689 \mathrm{~km}^{2}$ in high-mountain Asia (Table 1). Figure 13 shows the distribution of median glacier elevations 
Table 1. Summary of glaciers in the GGI, ICIMOD inventory, and the RGI, excluding glaciers smaller than $0.05 \mathrm{~km}^{2}$. The uncertainty in RGI ver. 4.0 was calculated using the error estimation equation (Eq. 1) in Pfeffer et al. (2014).

\begin{tabular}{lllrl}
\hline & & GGI & ICIMOD & RGI 4.0 \\
\hline Amudarya, Indus, Ganges, & Total area $\left[\mathrm{km}^{2}\right]$ & $43570 \pm 6536$ & 46826 & $57285 \pm 4212$ \\
Brahmaputra, and Irrawaddy basins & Excluded small glaciers & 6623 & 4060 & 4495 \\
\hline High-mountain Asia & Total area $\left[\mathrm{km}^{2}\right]$ & $91263 \pm 13689$ & - & $119878 \pm 9201$ \\
& Excluded small glaciers & 11181 & - & 6149 \\
\hline
\end{tabular}

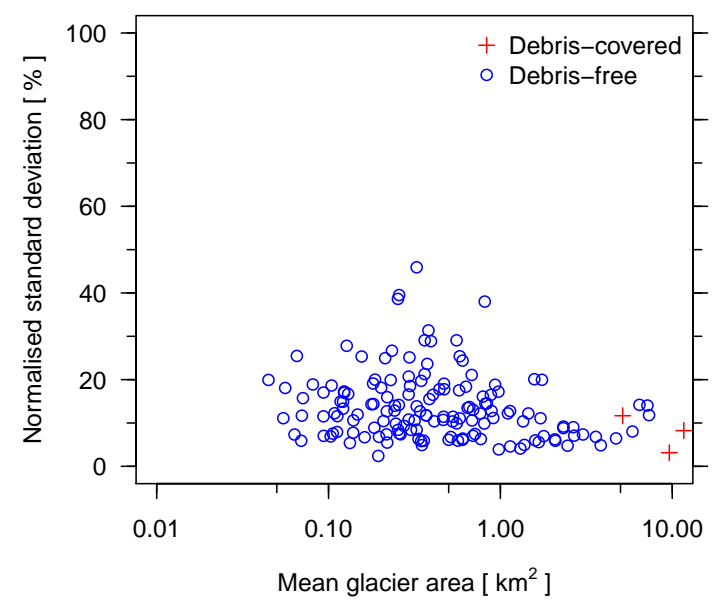

Figure 12. Normalised standard deviation of glacier area, based on delineations by different operators divided by the mean glacier area for all operators.

based on the GDEM2 and contour lines. Contour values represent the area-weighted average of median elevations within each $0.5^{\circ}$ grid cell. The area-weighted average of median elevations was based on the concept that the median elevation of larger glaciers is more representative of each region, because the mass balance (particularly accumulation) of smaller glaciers is affected by local topographic effects, such as snow drifting. This figure also shows the distribution of snow-line elevations estimated by Shi et al. (1980) and Shi (2008). The estimation method is described in Shi et al. (1980) as follows: "some firn line elevations were determined on the spot, while most were diagnosed according to topographical maps or calculated by Hôfer's method". Large-scale features evident in the distribution of snow-line elevations are consistent with our median-glacier elevations. These include a pronounced trough in southeastern Tibet, caused by intense precipitation along the Brahmaputra River (Liu et al., 2006; He, 2003), and a crest in western Tibet resulting from the prevailing arid, cold climate (Shangguan et al., 2007). Median elevation increases with distance from the moisture source, while areas of low median elevation are shown in the northwest, in the Himalaya and Karakoram ranges, as reported by Bolch et al. (2012).

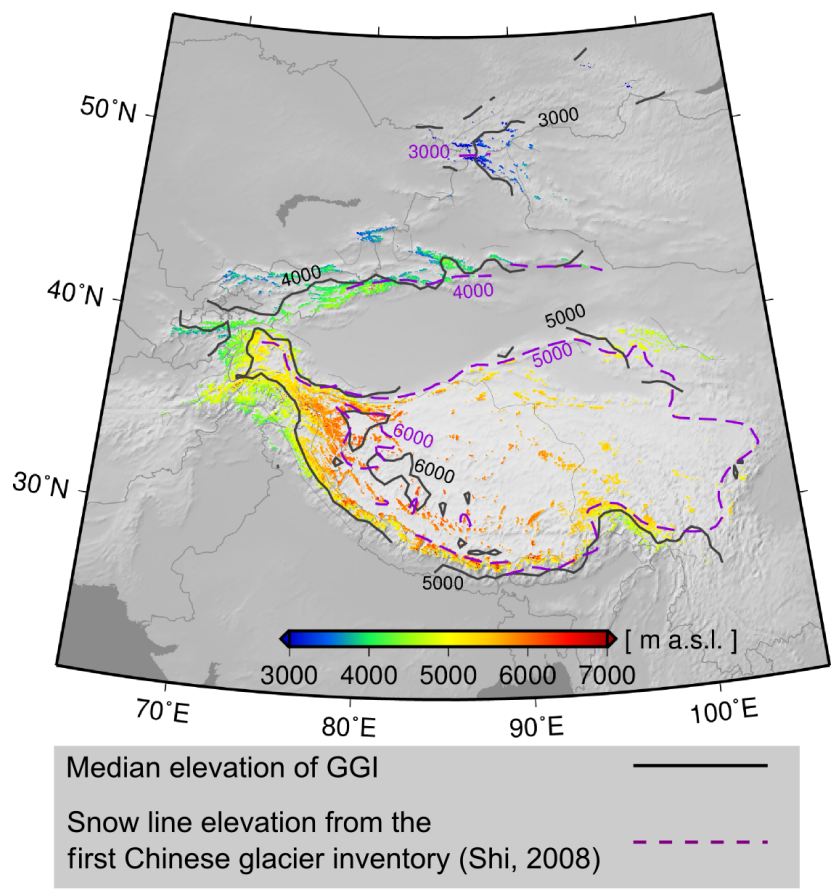

Figure 13. Distribution of glaciers in the GGI coloured by median elevation. Purple dashed contours indicate snow-line elevations used in the Chinese glacier inventory (Shi, 2008).

\subsection{Comparison of inventories in the $\mathrm{HKH}$ range}

We compared our GGI with the ICIMOD inventory (Bajracharya and Shrestha, 2011) in the HKH region, excluding from our assessment glaciers with an area of $<0.05 \mathrm{~km}^{2}$ so as to standardise the delineation of minimum glacier size among operators. In the following analysis, altitude data for both glacier inventories were derived from the GDEM2. Glacier area for each basin is given in Table 2. In addition, we compared the area for each area class and altitude (Fig. 14a and c). Although the total glacier area in the $\mathrm{HKH}$ range was less $(-7 \%)$ in the GGI than in the ICIMOD inventory, totals for each area class are strongly consistent between the inventories, with the exception of glaciers with areas between 16 and $32 \mathrm{~km}^{2}$ (Fig. 14a). In contrast, glacier hypsometry for the HKH range is less in the GGI than in the ICIMOD inventory for elevations between 5000 and $7000 \mathrm{~m}$ (Fig. 14c). 
Table 2. Summary of glaciers in the GGI, ICIMOD inventory, and the RGI 4.0. The uncertainty in the RGI ver. 4.0 was calculated using the error estimation equation (Eq. 1) in Pfeffer et al. (2014).

\begin{tabular}{|c|c|c|c|c|c|c|c|}
\hline & \multirow{3}{*}{$\begin{array}{r}\text { GGI } \\
\text { area } \\
{\left[\mathrm{km}^{2}\right]}\end{array}$} & \multicolumn{3}{|c|}{ ICIMOD inventory } & \multicolumn{3}{|c|}{ RGI 4.0} \\
\hline & & \multirow{2}{*}{$\begin{array}{r}\text { Area } \\
{\left[\mathrm{km}^{2}\right]}\end{array}$} & \multicolumn{2}{|c|}{ Difference } & \multirow{2}{*}{$\begin{array}{l}\text { Area } \\
{\left[\mathrm{km}^{2}\right]}\end{array}$} & \multicolumn{2}{|c|}{ Difference } \\
\hline & & & {$\left[\mathrm{km}^{2}\right]$} & {$[\%]$} & & {$\left[\mathrm{km}^{2}\right]$} & {$[\%]$} \\
\hline Amu Darya & 2498 & 2566 & 68 & 3 & $3154 \pm 256$ & 656 & 26 \\
\hline Indus & 23668 & 21193 & -2475 & -10 & $26018 \pm 1750$ & 2350 & 10 \\
\hline Ganges & 7537 & 9012 & 1475 & 20 & $10621 \pm 824$ & 3084 & 41 \\
\hline Brahmaputra & 9803 & 14020 & 4217 & 43 & $17419 \pm 1373$ & 7616 & 78 \\
\hline Irrawaddy & 64 & 35 & -29 & -45 & $73 \pm 9$ & 9 & 14 \\
\hline Salween & 1318 & 1352 & 34 & 3 & $2198 \pm 210$ & 880 & 67 \\
\hline Mekong & 225 & 235 & 10 & 4 & $586 \pm 49$ & 361 & 160 \\
\hline Yangtze & 1574 & 1660 & 86 & 5 & $2441 \pm 183$ & 867 & 55 \\
\hline Yellow & 132 & 137 & 5 & 4 & $189 \pm 16$ & 57 & 43 \\
\hline Tarim Interior & 2640 & 2310 & -330 & -13 & $2768 \pm 159$ & 128 & 5 \\
\hline Qinghai-Tibetan Interior & 7747 & 7535 & -212 & -3 & $10000 \pm 796$ & 2253 & 29 \\
\hline Total & 57204 & 60054 & 2850 & 5 & $75466 \pm 5625$ & 18262 & 32 \\
\hline
\end{tabular}

The glacier number, area, and median elevation for both inventories were compared for each $0.5^{\circ}$ grid cell (Fig. 15). Root mean square differences for these values are $28 \%$, $26 \%$, and $77.9 \mathrm{~m}$, respectively, and the inclinations of the fitted lines are close to 1 . We also evaluated the spatial distributions of glacier number, area, and the area-weighted mean of median elevation for each $0.5^{\circ}$ grid cell to identify differences between the GGI and the ICIMOD inventories (Fig. 16). We found that glacier area and number are greater in the GGI for the southern Karakoram and western Himalaya, but lesser in the northern Karakoram and central Himalaya (Fig. 16b). Moreover, while the total glacier area is less in the GGI than in the ICIMOD inventory, the number of glaciers in the Hengduan Shan is greater in the GGI. The median elevation of glaciers is considerably lower (200-300 m) in the GGI than in the ICIMOD inventory for the northern Hindu Kush and northern Karakoram (Fig. 16c), whereas in the central Himalaya the discrepancy is approximately $100 \mathrm{~m}$. Such inconsistency in median elevation for the northern Karakoram may be the product of inaccurate delineation in the shaded upper portions of glaciers (details of required GGI revisions are given in Table S5), whereas the discrepancy in the central Himalaya is probably due to our exclusion of steep headwalls.

\subsection{Comparison of inventories in high-mountain Asia}

To evaluate our entire inventory, we compared glacier area in the GGI and RGI across high-mountain Asia (27.0$54.9^{\circ} \mathrm{N}, 67.4-103.9^{\circ} \mathrm{E}$ ), focusing on glaciers $>0.05 \mathrm{~km}^{2}$ in area. Whereas total glacier area in the GGI is comparable to the ICIMOD inventory for the HKH range, this value is significantly lower (by $28615 \pm 22890 \mathrm{~km}^{2}$, or $-24 \pm 19 \%$ ) relative to the RGI for high-mountain Asia. Glaciers in the
RGI are larger than those in the GGI (Fig. 14b). Furthermore, glacier area between 4000 and $6000 \mathrm{~m}$ elevation is significantly greater in the RGI hypsometry than in the GGI (Fig. 14d). We suggest that these differences between inventories are due to four potential factors: (1) the result of real changes in glacier extent on the Tibetan Plateau since the 1970s (Ding et al., 2006; Li et al., 2008); (2) the omission of shaded glacier areas in the GGI; (3) the exclusion of steep headwalls in the GGI; and (4) the inclusion of seasonal snow cover at Hengduan Shan (Gardelle et al., 2013) and at Western Nyainqentanglha (Bolch et al., 2010) in the RGI, for which the data source is the first Chinese glacier inventory (Shi, 2008).

We also performed area comparison tests between the GGI and the GlobGlacier inventory (Frey et al., 2012) for the region covered by the latter. The GlobGlacier inventory was the source data for the RGI and so has already been integrated into the RGI with minor modification. The GGI and GlobGlacier give glacier areas of 8007 and $9270 \mathrm{~km}^{2}$, respectively, corresponding to a difference of $1263 \mathrm{~km}^{2}$, or $15 \%$. This area difference is consistent with the glacier definition employed by the GlobGlacier, which, like the RGI, includes upper steep headwall areas. This comparison shows that the considerable disparity in area between the GGI and RGI is due largely to differences in glacier definition in the western part of Himalaya that is covered by the GlobGlacier inventory.

Additionally, we compared total glacier area for the HKH regions according to the GGI against values from the RGI, the ICIMOD inventory (including Chinese basins (Bajracharya and Shrestha, 2011); Table 2), the inventory of Bolch et al. (2012), and GlobGlacier (Frey et al., 2012) (Table 3). The data sources for the inventory of Bolch et al. (2012) include the ICIMOD, GlobGlacier, and Chinese 
Table 3. Comparison of regionally aggregated total glacier areas from the GGI, Bolch et al. (2012) inventory, ICIMOD inventory, and the RGI. The uncertainty in the RGI ver. 4.0 was calculated using the error estimation equation (Eq. 1) in Pfeffer et al. (2014).

\begin{tabular}{|c|c|c|c|c|c|c|c|c|c|c|}
\hline & \multirow{3}{*}{$\begin{array}{r}\text { GGI } \\
\text { area } \\
{\left[\mathrm{km}^{2}\right]}\end{array}$} & \multicolumn{3}{|c|}{ Bolch et al. (2012) inventory } & \multicolumn{3}{|c|}{ ICIMOD inventory } & \multicolumn{3}{|c|}{ RGI 4.0} \\
\hline & & \multirow{2}{*}{$\begin{array}{l}\text { Area } \\
{\left[\mathrm{km}^{2}\right]}\end{array}$} & \multicolumn{2}{|c|}{ Difference } & \multirow{2}{*}{$\begin{array}{l}\text { Area } \\
{\left[\mathrm{km}^{2}\right]}\end{array}$} & \multicolumn{2}{|c|}{ Difference } & \multirow{2}{*}{$\begin{array}{l}\text { Area } \\
{\left[\mathrm{km}^{2}\right]}\end{array}$} & \multicolumn{2}{|c|}{ Difference } \\
\hline & & & {$\left[\mathrm{km}^{2}\right]$} & {$[\%]$} & & {$\left[\mathrm{km}^{2}\right]$} & {$[\%]$} & & {$\left[\mathrm{km}^{2}\right]$} & {$[\%]$} \\
\hline Karakoram & 17385 & 17946 & 561 & 3 & 13646 & -3739 & -22 & $19680 \pm 1052$ & 2295 & 13 \\
\hline Western Himalaya & 8402 & 8943 & 541 & 6 & 7696 & -706 & -8 & $9585 \pm 869$ & 1183 & 14 \\
\hline Central Himalaya & 8221 & 9940 & 1719 & 21 & 9575 & 1354 & 16 & $11502 \pm 899$ & 3281 & 40 \\
\hline Eastern Himalaya & 2836 & 3946 & 1110 & 39 & 3008 & 172 & 6 & $4605 \pm 362$ & 1769 & 62 \\
\hline Total & 36845 & 40775 & 3930 & 11 & 33924 & -2921 & -8 & $45372 \pm 3182$ & 8527 & 23 \\
\hline
\end{tabular}
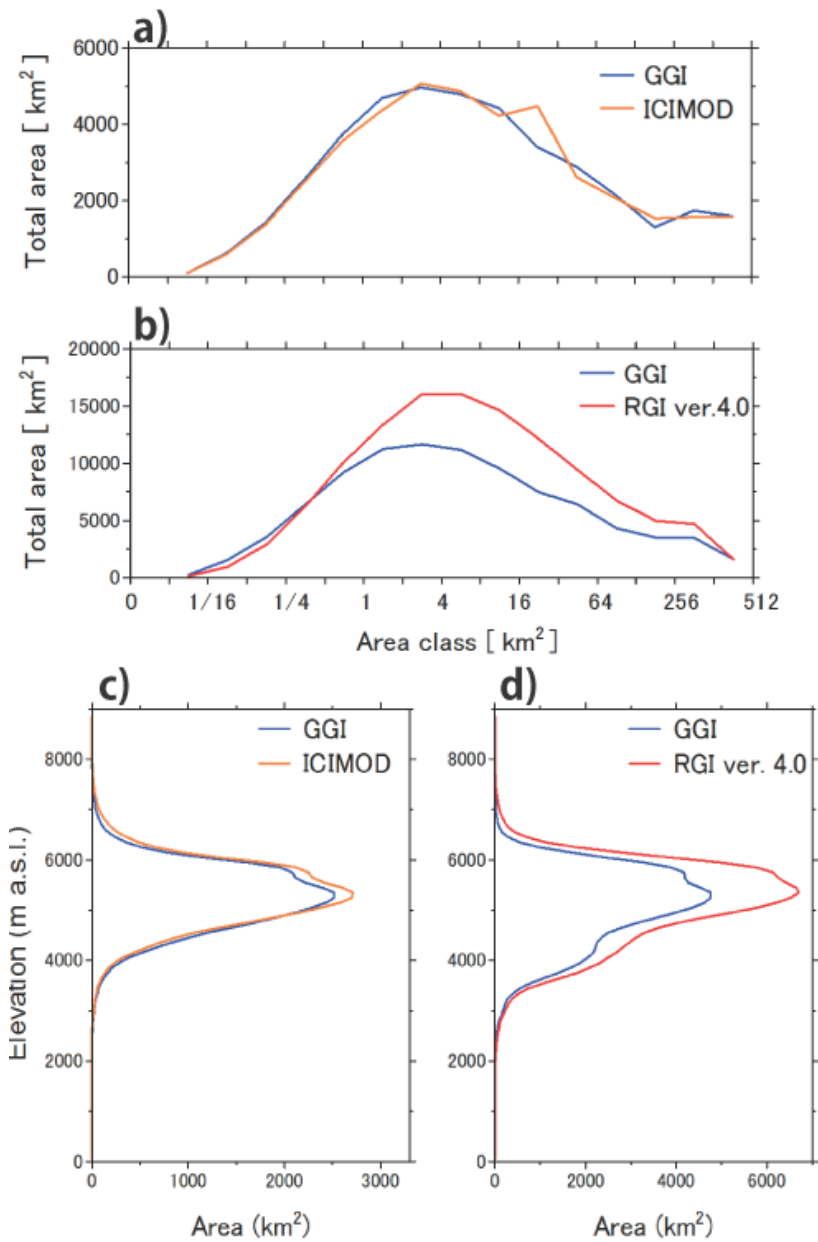

Figure 14. Size distributions of glacier area in the Hindu KushHimalaya range from the GGI and the ICIMOD inventories (a), and in high-mountain Asia from the RGI and GGI (b). Glacier hypsometries for the Hindu Kush-Himalaya range from GGI and ICIMOD (c) and high-mountain Asia derived from the GGI and RGI in $100 \mathrm{~m}$ bins (d). Only glaciers $>0.05 \mathrm{~km}^{2}$ in area are included in the calculation for each inventory. All hypsometries were calculated using the GDEM2. glacier inventories, as well as their own mapping. In the Karakoram, most of the data are derived from the ICIMOD inventory, with smaller contributions from the Chinese glacier inventory and their own mapping. For the western Himalaya, source data are derived largely from GlobGlacier, with contributions from the ICIMOD inventory, whereas data for the central Himalaya are sourced primarily from the ICIMOD inventory, with additional data from GlobGlacier. Similarly, the ICIMOD inventory is the primary data source for the eastern Himalaya, with additional input from the Chinese glacier inventory. Regional summaries for each inventory are given in Tables 2 and 3, and are shown in Fig. 17. Source satellite data for each were Landsat ETM+ images taken after 2000, meaning any time difference among the inventories is minor. Discrepancies in glacier area between the GGI and the ICIMOD inventory (including China) and Bolch et al. (2012) inventory are 7 and $11 \%$, respectively. As above, we suggest these inconsistencies result from the omission of shaded glacier areas and the elimination of high-angle glacier areas from the GGI, as well as different interpretations of debris-covered glaciers.

\section{Discussion}

\subsection{Intended purpose of the GGI}

We have excluded seasonally snow-covered areas and steep headwalls from our glacier delineations because our objective is to estimate total elevation change of glaciers. Kääb et al. (2012) reported that the inclusion of steep flanks, ice patches, ice-cored moraines, and rock glaciers can result in considerable differences among estimates of elevation change, particularly in the Himachal Pradesh, Nepal, and Bhutan Himalayas. Thus, in excluding such glacier ice-free areas, the GGI is well suited for estimating glacier elevation change.

While our strict criteria for the exclusion of steep upper headwalls will allow reliable elevation change of glaciers, we note that changes in glacier area cannot be estimated by comparison of the GGI to other glacier inventories, since each 

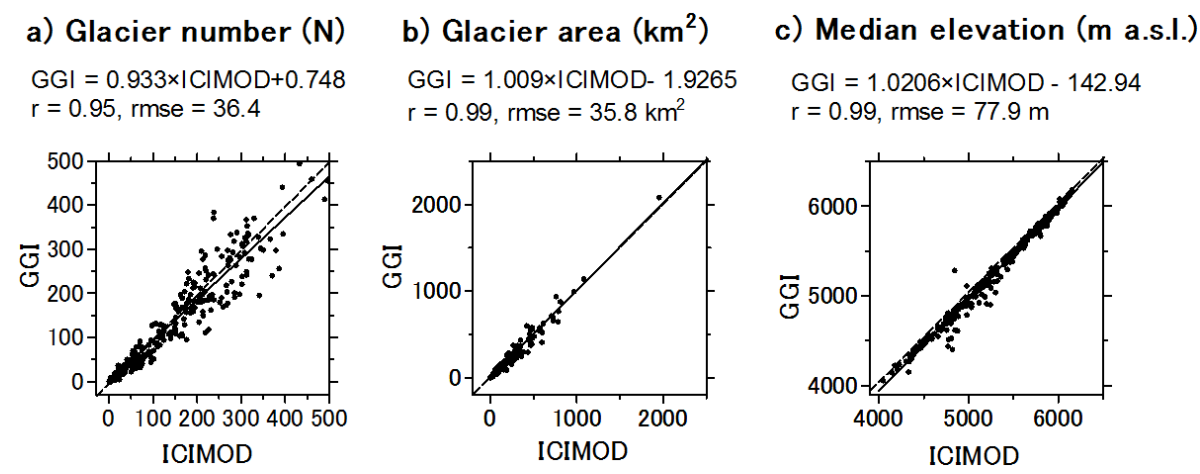

Figure 15. Scattergrams of (a) glacier number, (b) glacier area, and (c) area-weighted mean of median glacier elevation in each $0.5^{\circ}$ grid cell of the ICIMOD inventory, plotted against the GGI in the Hindu Kush-Himalaya range. The dashed lines indicate $1: 1$ correspondence between ICIMOD and GGI. Also shown is the root mean square number (or area) difference ratio (\%) against average number (or area) of ICIMOD. The solid lines are the best-fitting linear equations. All median elevations were calculated using the GDEM2.

will employ different criteria for delineating glacier boundaries (e.g. including all snow- or ice-covered walls). Assessment of area change, therefore, should only be made using the same definition criteria.

\subsection{Required revision for GGI by comparison with other inventories}

Our analysis shows that the total glacier area in the GGI is only $7 \%$ less than that of the ICIMOD inventory for the HKH ranges (Table 1). However, we note that considerable differences in the spatial distribution of glacier area and median elevation exist between the two inventories (Fig. 16b and c). We also analysed the distributions of area difference in both the upper and lower zones of glaciers, distinguished by the median elevation, for each $0.5^{\circ}$ grid cell. The normalised difference $(\%)$ is calculated as follows:

normalized difference of glacier area $=\frac{V_{\mathrm{ICIMOD}}-V_{\mathrm{GGI}}}{V_{\mathrm{GGI}}}$,

where the variable $(V)$ is the glacier area in each $0.5^{\circ}$ grid cell, and the subscript denotes the inventory. Area-weighted means of median elevation of GGI in each $0.5^{\circ}$ grid cell were used to distinguish the upper and lower zones for both inventories (Fig. 18).

Here, we investigate the differences in glacier area and median elevation between the ICIMOD inventory and GGI, focusing on several regions (Fig. S2). We also summarise the considerable revisions required for both glacier inventories in Table S5. The disparity in regional glacier area between the GGI and ICIMOD inventories cannot be explained by long-term changes in glacier area, since the acquisition dates of the source Landsat imagery are similar for both. Instead, we note that both inventories include topography where areas of shaded glacier ice have been omitted, and that this effect is highly variable regionally. For example, the GGI exhibits a smaller total glacier area than the ICIMOD inventory as a result of our inclusion of wintertime (and there- fore low solar angle) Landsat imagery (see Sects. 2 and 3.1). Similarly, median elevations for the eastern Pamir are notably lower (> 200 m) in the GGI than in the ICIMOD inventory (Fig. 16c), owing to the erroneous exclusion of shaded glacier areas.

Further discrepancy between the two inventories is caused by the variable identification of debris-covered glaciers. For example, the ICIMOD inventory identified debris-covered glaciers in the Hengduan Shan that are absent from our inventory. Such inconsistencies indicate that future revisions of glacier outlines must focus on (1) shaded glacier area and (2) debris-covered glaciers. Specifically, we will incorporate summertime Landsat images in order to delineate those glacier surfaces obscured by shade and use high-resolution Google Earth ${ }^{\mathrm{TM}}$ imagery to conduct a closer investigation of debris-covered glaciers. Finally, our exclusion of steep headwalls that are unaffected by glacier mass balance potentially discounts glaciers located on steep ground, resulting in an underestimation of total ice volume and median elevations in the GGI. In Landsat scenes where clear summertime imagery was unavailable, we employed heavily shaded wintertime imagery. Glacier outlines were then delineated with reference to contour lines derived from SRTM (see Sect. 3.3) (Fig. 8). However, differences in resolution between Landsat imagery $(30 \mathrm{~m})$ and SRTM data $(90 \mathrm{~m})$ mean that shaded glacier delineations based on contours are inherently less precise. To minimise this limitation in future revisions, the use of both simple band ratios (band 3/band 5) and additional thresholds in band 1 (blue) will help delineate shaded portions of debris-free glaciers (Rastner et al., 2012). Ultimately, revision of shaded glacier boundaries will reinforce our confidence in the quality of glacier outlines incorporated in the GGI. 

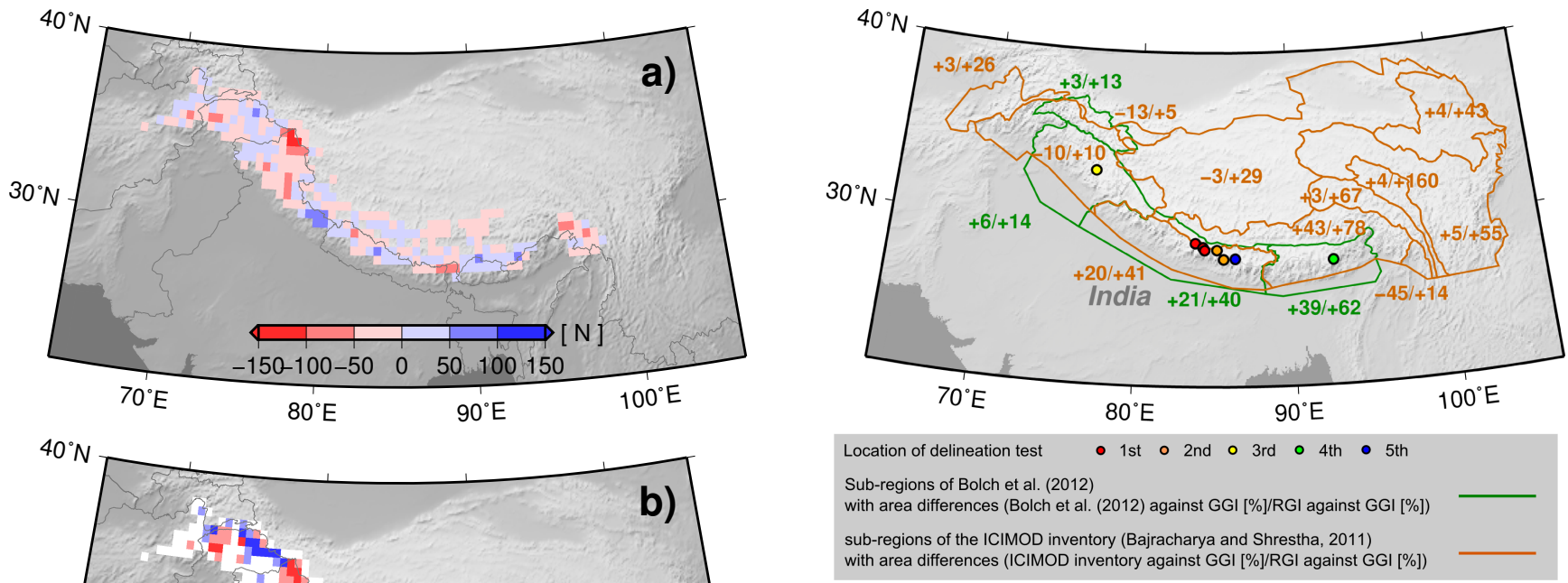

Figure 17. Overview of area comparisons and catchment outlines for each sub-region.
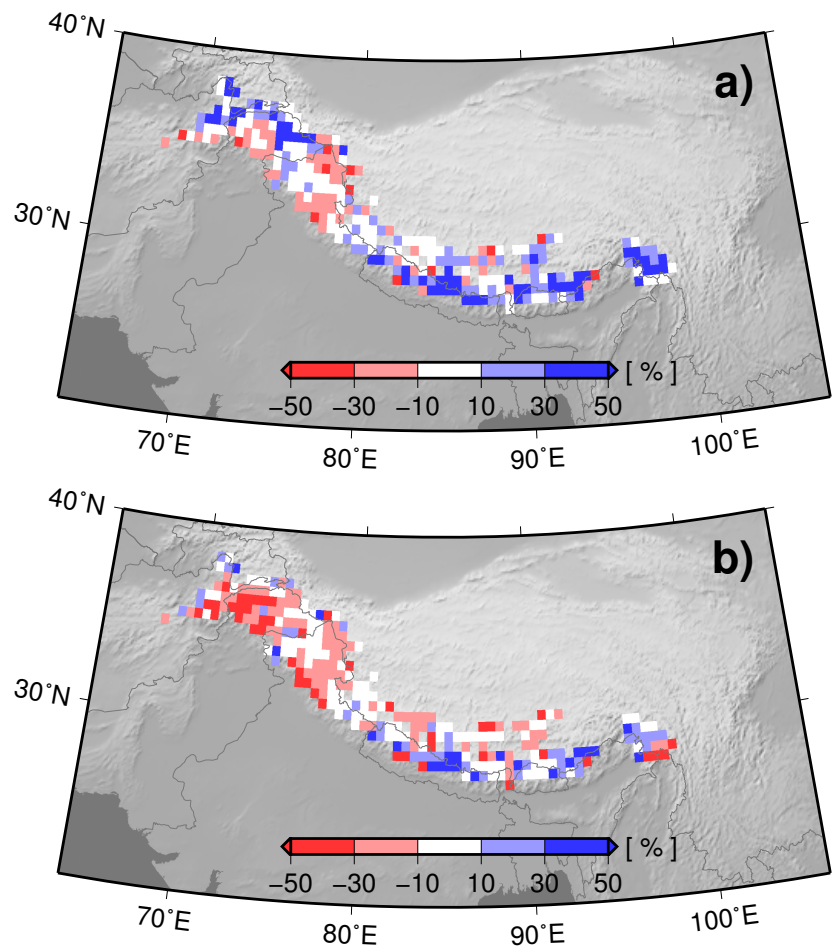

\subsection{Comparison between SRTM DEM and ASTER GDEM ver. 2}

As described above, we used the gap-filled SRTM DEM to support our delineation of glacier outlines and the GDEM2 to calculate median elevation (Fig. 13). Here, we compare areaweighted median elevations of glaciers derived using the two models for each $0.5^{\circ}$ grid cell (Fig. 19). In comparing the SRTM DEM with the GDEM2 data, we identified zones of lower median elevation in the SRTM at the southern edge of the Tibetan Plateau (30-31 $\left.{ }^{\circ} \mathrm{N}, 78.5-90.0^{\circ} \mathrm{E}\right)$, the western Himalaya, and parts of Hengduan Shan and the central

Figure 18. Normalised differences between glacier area in the (a) upper and (b) lower zones of the ICIMOD inventory and GGI for each $0.5^{\circ}$ grid cell in the Hindu Kush-Himalaya range.

Tien Shan (Fig. 19a). For both models, these regions show a larger standard deviation (40-280 m) in the difference in median glacier elevation (Fig. 19b). Evaluations by ICESat also suggest significant error in the SRTM DEM (Fig. 3c), which, if true, indicates regions of incorrectly interpolated data in the model. In the context of the GGI, application of invalid data to the Global Land Survey DEM during our geometric 

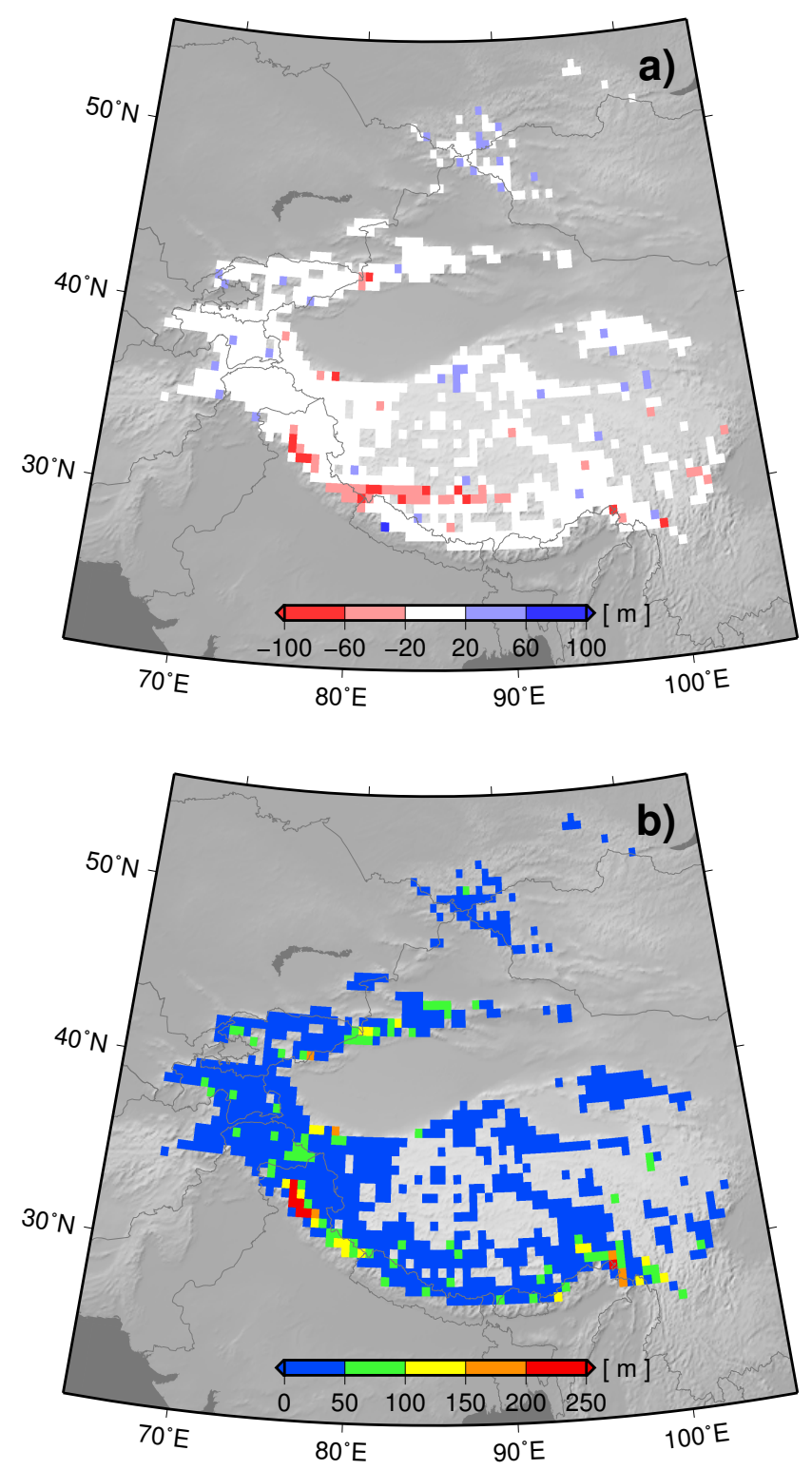

Figure 19. (a) Differences between area-weighted means of median elevations in the GGI derived from SRTM and those from GDEM2 (i.e. SRTM - GDEM2). (b) Standard deviations of the difference in median elevation of each glacier derived by SRTM and GDEM2 models. Grid cell size is $0.5^{\circ}$ for both.

correction of Landsat imagery would result in erroneous orthorectification and potentially imprecise glacier delineation.

\section{Conclusions}

We present a new glacier inventory for high-mountain Asia based primarily on ortho-calibrated Landsat ETM+ scenes from the period 1999-2003. The total glacier area determined by the GGI for the HKH range is similar to that of the ICIMOD inventory. Nonetheless, spatial differences in glacier number, area, and median elevation between the two inventories suggest significant regional variability. We propose that this variability is due primarily to the omission of shaded glacier areas from the GGI, resulting from our inclusion of wintertime Landsat imagery.

Our comparison of the entire GGI and RGI in highmountain Asia revealed that total glacier area is significantly less $(-24 \%)$ in the GGI than in the RGI (Table 1). The large discrepancies in glacier area between the two inventories are probably due to area change since the 1970s (e.g. the 1950s to 1970s in most of China in the RGI), the exclusion of shaded glacier areas from the GGI, and the inclusion of seasonal snow cover in the source data of the RGI. The definition of glacier extent, in particular the inclusion or exclusion of upper steep headwalls, is another potential cause of differences in total glacier area between the two inventories. This interpretation is supported by our comparison of the GGI and the GlobGlacier inventory in the western Himalaya, where the greater $(15 \%)$ glacier area in the GlobGlacier inventory reflects the inclusion of steep upper headwalls as glacier area.

To evaluate the contribution of these potential causes, further rigorous peer review by field-experienced operators is required before we can quantify the effects of recent changes in glacier area or differences in the criteria used to identify glacier area (e.g. steep headwalls).

\section{The Supplement related to this article is available online at doi:10.5194/tc-9-849-2015-supplement.}

Author contributions. The two first authors, T. Nuimura and A. Sakai, contributed equally and shared the responsibilities for this paper. K. Fujita contributed to discussions and writing the paper. H. Nagai contributed to designing the delineation methodology. $\mathrm{S}$. Takenaka contributed to the management and synchronisation of the inventory data. All other co-authors contributed to delineating glacier outlines.

Acknowledgements. We thank T. Bolch, G. Cogley, M. Pelto, S. R. Bajracharya, and F. Paul for their helpful comments that led to a considerably improved manuscript. We thank S. R. Bajracharya and B. Shrestha, without whom we could not have made a detailed comparison of our GAMDAM glacier inventory with the ICIMOD inventory. We also thank the RGI consortium for use of the RGI, the USGS for Landsat imagery, and CGIAR-CSI for gap-filled SRTM DEMs. We are grateful to S. Okamoto for assistance in selecting Landsat imagery. This project was supported by a grant from the Funding Program for Next Generation World-Leading Researchers (NEXT Program, GR052) and Grants-in-Aid for Scientific Research (26257202) of the Japan Society for the Promotion of Science.

Edited by: T. Bolch 


\section{References}

Arendt, A., Bliss, A., Bolch, T., Cogley, J. G., Gardner, A. S., Hagen, J.-O., Hock, R., Huss, M., Kaser, G., Kienholz, C., Pfeffer, W. T., Moholdt, G., Paul, F., Radić, V., Andreassen, L., Bajracharya, S., Barrand, N., Beedle, M., Berthier, E., Bhambri, R., Brown, I., Burgess, E., Burgess, D., Cawkwell, F., Chinn, T., Copland, L., Davies, B., de Angelis, H., Dolgova, E., Filbert, K., Forester, R., Fountain, A., Frey, H., Giffen, B., Glasser, N., Gurney, S., Hagg, W., Hall, D., Haritashya, U., Hartmann, G., Helm, C., Herreid, S., Howat, I., Kapustin, G., Khromova, T., König, M., Kohler, J., Kriegel, D., Kutuzov, S., Lavrentiev, I., LeBris, R., Lund, J., Manley, W., Mayer, C., Miles, E., Li, X., Menounos, B., Mercer, A., Mölg, N., Mool, P., Nosenko, G., Negrete, A., Nuth, C., Pettersson, R., Racoviteanu, A., Ranzi, R., Rastner, P., Rau, F., Raup, B., Rich, J., Rott, H., Schneider, C., Seliverstov, Y., Sharp, M., Sigurðsson, O., Stokes, C., Wheate, R., Winsvold, S., Wolken, G., Wyatt, F., and Zheltyhina, N.: Randolph Glacier Inventory - A Dataset of Global Glacier Outlines: Version 4.0, Global Land Ice Measurements from Space, National Snow and Ice Data Center, Boulder, USA, 2014.

Bajracharya, S. R. and Shrestha, B. (Eds.): The status of glaciers in the Hindu Kush-Himalayan region, International Centre for Integrated Mountain Development, Kathmandu, Nepal, 2011.

Bhambri, R., Bolch, T., and Chaujar, R.: Mapping of debris-covered glaciers in the Garhwal Himalayas using ASTER DEMs and thermal data, Int. J. Remote Sens., 32, 8095-8119, 2011.

Bolch, T., Yao, T., Kang, S., Buchroithner, M. F., Scherer, D., Maussion, F., Huintjes, E., and Schneider, C.: A glacier inventory for the western Nyainqentanglha Range and the Nam Co Basin, Tibet, and glacier changes 1976-2009, The Cryosphere, 4, 419433, doi:10.5194/tc-4-419-2010, 2010.

Bolch, T., Pieczonka, T., and Benn, D. I.: Multi-decadal mass loss of glaciers in the Everest area (Nepal Himalaya) derived from stereo imagery, The Cryosphere, 5, 349-358, doi:10.5194/tc-5349-2011, 2011.

Bolch, T., Kulkarni, A. Kääb, A., Huggel, C., Paul, F., Cogley, J. G., Frey, H., Kargel, J. S., Fujita, K., Scheel, M., Bajracharya, S., and Stoffel, M.: The state and fate of Himalayan Glaciers, Science, 336, 310-314, 2012.

Cogley, J. G.: Climate Science: Himalayan glaciers in the balance, Nature, 488, 468-469, doi:10.1038/488468a, 2012.

Ding, Y., Liu, S., Li, J., and Shangguan, D.: The retreat of glaciers in response to recent climate warming in western China, Ann. Glaciol., 43, 97-105, 2006.

Frey, H., Paul, F., and Strozzi, T.: Compilation of a glacier inventory for the western Himalayas from satellite data: methods, challenges, and results, Remote Sens. Environ., 124, 832-843, doi:10.1016/j.rse.2012.06.020, 2012.

Fujita, K. and Nuimura, T.: Spatially heterogeneous wastage of Himalayan glaciers, P. Natl. Acad. Sci. USA, 108, 14011-14014, 2011

Gardelle, J., Berthier, E., Arnaud, Y., and Kääb, A.: Region-wide glacier mass balances over the Pamir-Karakoram-Himalaya during 1999-2011, The Cryosphere, 7, 1263-1286, doi:10.5194/tc7-1263-2013, 2013.

Gardner, A., Moholdt, G., Cogley, J., Wouters, B., Arendt, A., Wahr, J., Berthier, E., Hock, R., Pfeffer, W., Kaser, G., Ligtenberg, S., Bolch, T., Sharp, M., Hagen, J., van den Broeke, M., and Paul, F.: A reconciled estimate of glacier contribu- tions to sea level rise: 2003 to 2009 , Science, $340,852-857$, doi:10.1126/science.1234532, 2013.

Hayakawa, Y., Oguchi, T., and Lin, Z.: Comparison of new and existing global digital elevation models: ASTER GDEM and SRTM-3, Geophys. Res. Lett., 35, L17404, doi:10.1029/2008GL035036, 2008.

He, Y.: Changing features of the climate and glaciers in China's monsoonal temperate glacier region, J. Geophys. Res., 108, 1-7, doi:10.1029/2002JD003365, 2003.

Immerzeel, W., van Beek, L. P. H., and Bierkens, M.: Climate change will affect the Asian water towers, Science, 328, 1382 1385, doi:10.1126/science.1183188, 2010.

Jacob, T., Wahr, J., Pfeffer, W., and Swenson, S.: Recent contributions of glaciers and ice caps to sea level rise, Nature, 482, 514-518, 2012.

Jarvis, A., Reuter, H., Nelson, A., and Guevar, E.: Hole-filled SRTM for the globe Version 4, available from the CGIARCSI SRTM 90 m Database, http://srtm.csi.cgiar.org/, last access: 28 March 2014.

Kääb, A.: Glacier volume changes using ASTER satellite stereo and ICESat GLAS laser altimetry. A Test Study on Edgeøya, Eastern Svalbard, IEEE T. Geosci. Remote, 46, 2823-2830, 2008.

Kääb, A., Berthier, E., Nuth, C., Gardelle, J., and Arnaud, Y.: Contrasting patterns of early twenty-first-century glacier mass change in the Himalayas, Nature, 488, 495-498, doi:10.1038/nature11324, 2012.

Kaser, G., Grosshauser, M., and Marzeion, B.: Contribution potential of glaciers to water availability in different climate regimes, P. Natl. Acad. Sci. USA, 107, 20223-20227, 2010.

Li, X., Cheng, G., Jin, H., Kang, E., Che, T., Jin, R., Wu, L., Nan, Z., Wang, J., and Shen, Y.: Cryospheric change in China, Global Planet. Change, 62, 210-218, 2008.

Liu, S., Shangguan, D., Ding, Y., Han, H., Xie, C., Zhang, Y., Li, J., Wang, J., and Li, G.: Glacier changes during the past century in the Gangrigabu mountains, southeast QinghaiXizang (Tibetan) Plateau, China, Ann. Glaciol., 43, 187-193, doi:10.3189/172756406781812348, 2006.

Matsuo, K. and Heki, K.: Time-variable ice loss in Asian high mountains from satellite gravimetry, Earth Planet. Sc. Lett., 290, 30-36, 2010.

McClung, D. and Schaerer, P.: The Avalanche Handbook, 3rd Edn., The Mountaineers Books, Seattle, 342 pp., 2006.

Paul, F., Huggel, C., and Kääb, A.: Combining satellite multispectral image data and a digital elevation model for mapping debriscovered glaciers, Remote Sens. Environ., 89, 510-518, 2004.

Paul, F., Barrand, N., Baumann, S., Berthier, E., Bolch, T., Casey, K., Frey, H., Joshi, S., Konovalov, V., Le Bris, R., Mölg, N., Nosenko, G., Nuth, C., Pope, A., Racoviteanu, A., Rastner, P., Raup, B., Scharrer, K., Steffen, S., and Winsvold, S.: On the accuracy of glacier outlines derived from remote-sensing data, Ann. Glaciol., 54, 171-182, doi:10.3189/2013AoG63A296, 2013.

Pfeffer, W. T., Arendt, A. A., Bliss, A., Bolch, T., Cogley, J. G., Gardner, A. S., Hagen, J. O., Hock, R., Kaser, G., Kienholz, C., Miles, E. S., Moholdt, G., Mölg, N., Paul, F., Radić, V., Rastner, P., Raup, B. H., Rich, J., Sharp, M. J., and the Randolph Consortium: The Randolph Glacier Inventory: a globally complete inventory of glaciers, J. Glaciol., 60, 537-552, 2014. 
Racoviteanu, A., Paul, F., Raup, B., Khalsa, S., and Armstrong, R.: Challenges and recommendations in mapping of glacier parameters from space: results of the 2008 Global Land Ice Measurements from Space (GLIMS) workshop, Boulder, Colorado, USA, Ann. Glaciol., 50, 53-69, doi:10.3189/172756410790595804, 2009.

Radić, V. and Hock, R.: Regionally differentiated contribution of mountain glaciers and ice caps to future sea-level rise, Nat. Geosci., 4, 91-94, doi:10.1038/ngeo1052, 2011.

Raper, S. C. B. and Braithwaite, R.: The potential for sea level rise: New estimates from glacier and ice cap area and volume distributions, Geophys. Res. Lett., 32, L05502, doi:10.1029/2004GL021981, 2005.

Rastner, P., Bolch, T., Mölg, N., Machguth, H., Le Bris, R., and Paul, F.: The first complete inventory of the local glaciers and ice caps on Greenland, The Cryosphere, 6, 1483-1495, doi:10.5194/tc-6-1483-2012, 2012.

Raup, B. and Khalsa, S.: GLIMS analysis tutorial, Boulder, CO, University of Colorado, National Snow and Ice Data Center, http://www.glims.org/MapsAndDocs/guides.html (last access: 28 January 2014), 2007.
Salerno, F., Buraschi, E., Bruccoleri, G., Tartari, G., and Simiraglia, C.: Glacier surface-area changes in Sagarmatha national park, Nepal, in the second half of the 20th century, by comparison of historical maps, J. Glaciol., 54, 738-752, 2008.

Shangguan, D., Liu, S., Ding, Y., Li, J., Zhang, Y., Ding, L., Wang, X., Xie, C., and Li, G.: Glacier changes in the west Kunlun Shan from 1970 to 2001 derived from Landsat TM/ETM+ and Chinese glacier inventory data, Ann. Glaciol., 46, 204-208, doi:10.3189/172756407782871693, 2007.

Shi, Y. (Ed.): Concise Glacier Inventory of China, Shanghai Popular Science Press, China, 2008.

Shi, Y., Hsieh, T., Cheng, P., and Li, C.: Distribution, features and variations of glaciers in China, IAHS Publ., 126, 111-116, 1980.

Thakuri, S., Salerno, F., Smiraglia, C., Bolch, T., D’Agata, C., Viviano, G., and Tartari, G.: Tracing glacier changes since the 1960 s on the south slope of Mt. Everest (central Southern Himalaya) using optical satellite imagery, The Cryosphere, 8, 1297-1315, doi:10.5194/tc-8-1297-2014, 2014.

Yao, X., Liu, S., Sun, M., Wei, J., and Guo, W.: Volume calculation and analysis of the changes in moraine-dammed lakes in the north Himalaya: a case study of Longbasaba lake, J. Glaciol., 58, 753-760, 2012. 